\title{
Systematic Review of Knowledge Acquisition and Representation Techniques
}

\section{Revisión sistemática de técnicas de adquisición \& representación de conocimiento}

\author{
Diana Magally Forero ${ }^{1 *}$, Álvaro Javier Martínez Acevedo ${ }^{2}$, Laura Patricia Pinto Prieto ${ }^{3,}$ Luis \\ Eduardo Becerra Ardila ${ }^{4}$
}

\author{
${ }^{1}$ Universidad Industrial de Santander, Santander, Colombia, dimafo14@ hotmail.com \\ ${ }^{2}$ Universidad Industrial de Santander, Santander, Colombia, alvaroja0315@hotmail.com \\ ${ }^{3}$ Universidad Industrial de Santander, Santander, Colombia Laura.pinto@correo.uis.edu.co \\ ${ }^{4}$ Universidad Industrial de Santander, Santander, Colombia lbecerra@uis.edu.co
}

Published 30 July 2014

\begin{abstract}
The need to create mechanisms or systems to acquire, represent, and convey knowledge is one of the problems that have been given priority over years of research; the need for acquisition has generated the need for more compact models that conserve implicit and explicit knowledge generated within organizations. Within this environment, due to changes generated by knowledge management, enterprises recognize the importance of managing these intangible assets as a requirement to stay in the market and adapt to organizational and technological changes. Each organization must find its own way and recognize that intellectual capacity has become an important factor for the success of organizational development. The aim of this paper was to present the results of a systematic literature review through which we identified some knowledge acquisition and representation techniques that can be replicated in organizations to leverage internal and external knowledge to the organization and achieve sustainable competitive advantages. The results present administrative techniques related to organizational culture and values, as well as the definition of different types of alliances also identified as expert system technologies and social tools useful for knowledge acquisition and representation.
\end{abstract}

Key words: Knowledge Management, Knowledge Acquisition, Knowledge Representation, organizational development

\section{Resumen}

La necesidad de crear mecanismos o sistemas que permitan adquirir, representar y transmitir el conocimiento es uno de los problemas con prioridad que se ha dado en el transcurrir de los años de investigación; esta necesidad de adquisición ha generado la necesidad de contar con modelos más compactos que permitan conservar el conocimiento implícito y explicito que se genera dentro de las organizaciones. En este entorno, debido al cambio que ha generado la gestión del conocimiento, las empresas reconocen la importancia que tiene el manejo de estos bienes intangibles, como requisito para permanecer en el mercado y adaptarse a cambios organizativos y tecnológicos, cada organización debe encontrar su propio camino y reconocer que la capacidad intelectual se ha convertido en un factor importante para el éxito del desarrollo organizacional. El objetivo de este artículo es presentar los resultados de una revisión sistemática de la literatura mediante la cual se identifican algunas técnicas de adquisición y representación del conocimiento, que se pueden replicar en las organizaciones para aprovechar el conocimiento interno y externo a la organización y lograr ventajas competitivas sostenibles. Los resultados presentan técnicas administrativas relacionadas con la cultura y valores organizativos, así como la definición de diferentes tipos de alianzas, asimismo se identificaron tecnologías como los sistemas expertos y las herramientas sociales como útiles para la adquisición y representación de conocimiento.

Palabras clave: Adquisición del Conocimiento, Desarrollo organizativo, Gestión del conocimiento, Representaciones de conocimiento, Técnicas y prácticas de gestión de conocimiento 


\section{TECCIENCLA}

\section{Introduction}

In today's world under the influence of the new paradigm of the information society and of the knowledge-based economy, society has the capacity to generate, appropriate, and use knowledge to develop competitive advantages; based on the aforementioned, we can state that intellectual capital has become a fundamental factor within the competitiveness of an organization, hence, knowledge is recognized as the principal source of competitive advantage, especially due to its intangible nature, which makes it difficult to imitate [1].

The first investigations on knowledge management (KM) propose a perspective centered on the process of acquisition, representation, and exchange of knowledge in organizations [2]. "Knowledge" would substitute machinery, equipment, capital, raw material, and work to become the most important factor in industrial productivity. Hence, knowledge in organizations is not merely a core skill to cultivate, but also a key element for the organization's survival in the market [3].

Some studies have focused on defining processes and activities that comprise knowledge management; however, consensus has not been reached with the scientific community in this aspect, thus, finding processes that are common in some works but which vary in the applicability that has been assigned to them. In this sense, some authors coincide in knowledge management activities like identifying, acquiring or capturing, sharing, and using knowledge others introduce to the activity of knowledge creation or generation as a starting point to manage knowledge. A model referenced in the literature is the knowledge creation cycle proposed by Nonaka, which suggests that knowledge creation activities include socialization, externalization, combination, and internalization [2]. Likewise, processes of knowledge representation or modeling are mentioned as key processes to support systems analysis to discuss strategic issues of knowledge management and plan knowledge management din different ways [1].

Within this environment, due to the change knowledge management has generated, enterprises recognize the importance of managing these intangible goods, as requisite to remain in the market and adapt to organizational and technological changes; each organization must find its own path and recognize that intellectual capacity has become an important factor for the success of the organizational development, hence, this investigation centers on the systematic review in search of techniques of acquisition and representation of knowledge, through a review of the literature consulted in databases like ISI Web of Knowledge, SCOPUS, and guide texts, finding some techniques that support management and representation of knowledge, becoming a contribution to the scientific community and to future interested investigations.

Currently, each society has its own knowledge assets. Hence, it becomes necessary to work to connect the forms of knowledge societies already have, accomplishing acquisition and dissemination of such in the organization. However, many of these organizations have not reached this new era because the majority has not been capable of transforming the information found internally and externally in knowledge that generates value to the organization [4]. Converting the information into knowledge that can be used by the organization requires acquisition techniques and models found in the literature, especially those practices that have generated successful results within organizations [5].

Through the use of adequate techniques to acquire and represent knowledge, we may contribute for this knowledge being identified and embodied, whether in organizational documents or managed by using information technologies, to truly contribute to generating competitive advantages. Likewise, these techniques can help organizations so that when knowledge is acquired it can be shared and socialized with different personnel to ensure everyone having the same perspective of the knowledge required and, thus, contribute to reducing information management.

This study was developed in seven parts; the first shows the contextualization of the research carried out. Then, the methodology used for this research is shown. Parts 3, 4, and 5 propose the theoretical framework product of the literature review; section 6 identifies the results on the techniques of knowledge acquisition and representation and information technologies that can support these processes of knowledge management and, lastly, section 7 identifies the conclusions reached with the investigation.

\section{Methodology}

The results of this investigation are based on a literature review. Initially, an analysis was performed of relevant publications to create a theoretical framework that serves as the base for the investigation, bearing in mind definitions and history identified on the acquisition and representation of knowledge, activities that can be developed within it and the technologies used. This 样 
literature review permits identifying key words that later provide a systematic review to identify the techniques of acquisition and representation of knowledge.

Specifically, this research proceeded to search in the ISI Web of Knowledge database because it is an international scientific reference and has quality articles during 2001-2012, permitting analysis on the importance generated in the scientific community by the process of knowledge acquisition and representation within organizations. Likewise, with the term previously identified a search equation was generated, which along with the database generates pertinent information for this study, analyses are made regarding the publications, reviewing the quality of the articles and identifying those that do not show relevant information.

Key words are used to exclude and include articles, choosing to read documents that included terms like knowledge management, knowledge acquisition, knowledge representation, knowledge-based systems, and organizational performance, among others. Thereafter, the abstracts were analyzed to identify the content of the articles and the documents were read to identify the importance of the processes of knowledge acquisition and representation and the impact it generates in organizations.

Due to this systematic process, some techniques have been identified that supported on information technologies can allow organization to become market leaders, generate competitive advantage, as well as have pertinent information across the organization. It permits all the stakeholders to have precise information that permits improving their organizational processes.

\section{Theoretical basis}

\subsection{Background of Knowledge Management}

The first author who referred to the importance of knowledge management was economist Alfred Marshall in his work "Principles of Economics" published in 1890; Marshall highlighted the influence not only knowledge in organizations but the creation of new knowledge in the industrial economy upon seeing that neoclassic organizations were focused on using existing knowledge represented by price information. Marshall (2010) stated: "knowledge is our most powerful production machine; it allows us to subject nature and obligate it to satisfy our needs".

After this event, (Hayek and Schumpeter 1994), economists from the Austrian school, were the main representatives to highlight the preference of knowledge in each economic subject rather than focusing on group and shared knowledge. While Hayek remained in the efficient use of existing knowledge, (Schumpeter,1994) developed a dynamic theory of economic development, which states that change generated endogenously within the economy is provoked by the innovative activities of entrepreneurs, these being the only agents capable of carrying out new combinations of resources and the transformation of the forms of organization. For Schumpeter, the origin of economic development in organizations lies in processes of technological innovation, but this innovation must be radical to trigger revolutionary changes; in turn, generation of this radical innovation is given by the constant flow of knowledge that will always be offered and accumulated in all types of people.

Two-hundred years after the Industrial Revolution, society goes from being capitalist to a postindustrial society - the society of knowledge [3]. This is why Druker has had significant influence in administration, given that he based entrepreneurial development on the formation of knowledge in organizations. We are entering the knowledge society, where the classical economic resource is no longer capital, material resources, or labor, but now it is and will be knowledge, where those using knowledge will play a central role [6]. In this society the most important resource and generator of absolute wealth is no longer capital, natural resources, or labor; it is knowledge. This factor is decisive in the competitiveness of international markets and, in turn, the principal cause of success in economic development. Also, in his book: The Third Wave, the author highlights the emergence of globalization through the technological development of telecommunications. These new information technologies are the new sources of value by constituting important savings in organizations. Toffler mentions that knowledge, creativity, and information are the factors that replace money, the work force, and the natural resources because they are the biggest assets the whole organization has and the best distributors of power in societies [7].

Additionally, Nonaka and Takeouchi propose a model as a process to generate new knowledge as a possible formula for entrepreneurial success, but for it to take place, said new knowledge must be distributed throughout the organization and represented through new technologies or products [8]. Said model mentioned previously is a process carried out to identify tacit knowledge and convert it into explicit knowledge through four phases that circulate spirally: socialization, externalization, combination, and internalization.

Implementation of knowledge management provides 


\section{TECCIENCIA}

multiple organizational advantages; some are directly correlated with savings, while others are more difficult to quantify. Two general benefits are found and, in turn, others are derived related with the results of the process and the organizational results [9].

\section{General benefits [10]}

- Improve performance of the organization through efficiency, productivity, quality, and innovation.

- Reach high competitiveness indexes by having greater access to employee Know-How through improved decisions, processes, and reduction of activities that do not add value.

Author's elaboration: Source: Alavi and Leidner (1999). [11]

\subsection{Processes de Knowledge acquisition and representation.}

Performance in organizations frequently increases when among their strategies their priority is to acquire and manage resources based on knowledge; however, management of the knowledge base requires a systematic effort to capture it and from its acquisition generate new knowledge bases, thus, organizations create the capacity to capture and generate knowledge yielding as a result more precise decisions, innovation in products or services, and improvement of processes [2].

Researchers concentrate their efforts on strategies for knowledge acquisition in employees and managers; employees acquire and maintain valuable knowledge implicitly, and the function of organizations is to coordinate, manage, and achieve its representation and transference. It is clear that all learning starts at the individual level and grows in the social context and within the organization [12]; however, it is important to recognize that effectiveness and organizational culture are two factors that influence directly within the process of inter-organizational acquisition, representation, and transference. Although knowledge acquisition is generally understood as a type of human learning, the knowledge engineering community took the word in the sense of "teaching" a computer to imitate through the construction of a knowledge base, or at least it could be the a functional equivalent of human knowledge domain. "Intrinsic human needs and human capacities have remained constant during millennia" [13]. In other words, systems should be designed that naturally comply with satisfying these needs and skills of the organization.

Hamel (1991) define acquisition of new specialized knowledge as: "the motivation to establish interorganizational collaboration"
Knowledge acquisition is a process of knowledge management, which consists in acquiring knowledge from various resources, like documents, reports, the internet, and experts. This process is considered important, given the limitations of the enterprise to selfgenerate all the knowledge that implies its rational and efficient use.

Hence, knowledge acquisition centers its attention on the search for tools to identify, select, and use external knowledge to benefit the organization. Knowledge representation is an important area of intelligence, emphasizing on the selection of an adequate structure to represent a component of knowledge within a specific context; with such, knowledge from the real world can be used in problem solving and in reasoning.

To satisfy needs, systems designers must identify in depth the situation to investigate, considering ideas from psychology, given that knowledge is represented in different classes: experience, common sense, metaknowledge, semantics, and ontology [14]. With the emergence of computer science, information technology, and artificial intelligence, knowledge representation acquires priority given that it now seeks for automated systems to capture, store, transmit, evaluate, and generate knowledge; one of the transcendental points is to get artificial intelligence to represent knowledge in automated manner [15].

Knowledge representation is a method through which an adequate structure is selected to represent a knowledge base, so that storage, recovery, inference, and reasoning are facilitated without disturbing the characteristics of this previously acquired knowledge base, the manner in which knowledge is represented influences upon the effectiveness in which that knowledge can be shared and reconstructed; generally, knowledge is presented linearly, following a hierarchical structure. Identification of a good knowledge representation strategy permits achieving efficiency in the calculation, human expression, and reasoning bases; it is more a knowledge structure than a data structure because the knowledge structure may contain data and information [16].

One of the main objectives of knowledge representation is data acquisition through experts or induced from one data set to be subsequently represented in a format that is understandable to humans and at the same time can be executed by computers. Different methods exist to achieve knowledge representation among which we can find semantic networks, frameworks, first-order logic, production of standards, and decision tables among others. 
Table 1. Benefits in results of Processes and Organizational results [7].

\begin{tabular}{|l|l|l|l|l|}
\hline RESULTS OF THE PROCESS & ORGANIZATIONAL RESULTS & GERKETING & GENERAL \\
\hline COMMUNICATION & EFFICIENCY & FINANCIAL & MARE & $\begin{array}{l}\text { Convincing proposals } \\
\text { multinational clients }\end{array}$ \\
\hline Improve communication. & Reduce time to solve problems. & Increase sales. & Improve service. & Improve project management. \\
\hline Speed up communication. & Diminish time of proposals & Diminish costs. & Focus on the client. \\
\hline $\begin{array}{l}\text { Most visible opinions of } \\
\text { the personnel. }\end{array}$ & Speed up results. & Greater benefits. & Direct Marketing. & Reduction de personal. \\
\hline Increase participation & Speed up market delivery. & & Proactive Marketing. & \\
\hline & Greater global efficiency. & & & \\
\hline
\end{tabular}

\section{Results}

\subsection{Identification of Techniques of knowledge acquisition and representation}

Knowledge acquisition and representation can be manifested through the use of adequate techniques and can help knowledge to be identified and embodied in organizational documents or managed by using information technologies, these processes in knowledge management permit organizations to generate competitive advantage; knowledge can be shared and socialized in the different work groups in the organization, permitting a transversal vision of the knowledge necessary in it [17].

Some techniques of knowledge acquisition and representation identified during the literature review are described in Table 2, along with the technologies that can support these two processes of knowledge management, a brief description is made of the utility that can be generated from it; likewise, it may be discerned that these techniques are in a state of advanced maturity, and that their possible implementation depends on the organizational culture and on the strategic objectives proposed by the organization.

Table 2. Administrative techniques for knowledge acquisition and representation

\begin{tabular}{|c|c|c|}
\hline \multicolumn{3}{|r|}{ Administrative techniques } \\
\hline \multirow{3}{*}{$\begin{array}{l}\text { Organizati } \\
\text { on to } \\
\text { learning }\end{array}$} & Visualization & $\begin{array}{l}\text { These are visual media like animation, photo-grams, or illustrations to communicate, implement, and } \\
\text { monitor decisions in systematic, ordered, and disciplined manner [18]. }\end{array}$ \\
\hline & Conceptual maps & $\begin{array}{l}\text { Conceptual maps serve to organize, rank, and represent knowledge about concepts and/or financial } \\
\text { processes. [19] }\end{array}$ \\
\hline & $\begin{array}{l}\text { Organizational } \\
\text { generativity }\end{array}$ & $\begin{array}{l}\text { These are surveys applied to internal members of the organizations to know their needs, expectations, } \\
\text { experiences, identification of problems, and possible solutions [20]. }\end{array}$ \\
\hline \multirow{3}{*}{$\begin{array}{l}\text { Organizational } \\
\text { values }\end{array}$} & Motivation & $\begin{array}{l}\text { The level of social interaction determines success or failure of knowledge management, which is why } \\
\text { employees must remain with positive attitudes given that this behavior develops a natural vision to } \\
\text { acquire, use, share, and exchange knowledge without sensing that they are work requirements [21], [22], } \\
{[23],[24],[25],[26],[27],[28] \text {. }}\end{array}$ \\
\hline & $\begin{array}{l}\text { Entrepreneurial } \\
\text { commitments }\end{array}$ & $\begin{array}{l}\text { Organizational commitments and agreements are used to disseminate these strategies traced by the } \\
\text { organization, providing a guide for upper management to draw out action plans to reach the objectives } \\
\text { traced [29]. }\end{array}$ \\
\hline & Leadership & $\begin{array}{l}\text { Leaders are considered one of the essential components of an organization because they provide a } \\
\text { communication cannel based on mutual trust with the members of the organization [30], [31]. }\end{array}$ \\
\hline \multirow{2}{*}{$\begin{array}{l}\text { Strategic } \\
\text { alliances }\end{array}$} & Alliances with partners & $\begin{array}{l}\text { Establishing alliances with partners provides skills and capacities organizations need to achieve thein } \\
\text { strategic objectives [32]. Alliances with partners lessen organizational problems derived from processes of } \\
\text { social identification and of pertinence [33], [34]; to select these alliances, partners are on elected based on } \\
\text { their history of achievements or on the success of prior links [35], [36]. }\end{array}$ \\
\hline & $\begin{array}{l}\text { University- } \\
\text { Enterprise alliance }\end{array}$ & $\begin{array}{l}\text { Create university-enterprise alliances for universities through r\&d to contribute significantly to } \\
\text { innovation in organizations and industries help to improve the current theory providing universities a } \\
\text { greater approach to practical reality [37]. }\end{array}$ \\
\hline
\end{tabular}




\section{TECCIENCLA}

Table 3 shows some technologies that support techniques of knowledge acquisition and representation exposed in the previous table; among these, we analyze the WEB 2.0 adopted in organizations and leading them to work faster and generating information flow among the units of the organization. We can also name systems based on cases like a computational structure that permits finding optimal solutions to entries of problems generated in the organization; these solutions emerge through identifying experiences already lived, likewise, virtual communities allow interested parties to generate knowledge within and outside the organization to convert it into useful information for decision making guided with the strategic objectives of the organization.

Table 3. Technologies that support processes of knowledge acquisition and representation

\begin{tabular}{|c|c|c|}
\hline \multicolumn{3}{|c|}{ Information technologies } \\
\hline \multirow{4}{*}{ Systems experts } & Repositories of knowledge & $\begin{array}{l}\text { Capture knowledge obtained from different projects and store it in organization } \\
\text { repositories [38]. }\end{array}$ \\
\hline & Reasoning based on cases & $\begin{array}{l}\text { Centered on descriptions of past experiences of specialists, represented as } \\
\text { cases, which are stored in a database for their subsequent recovery when a new } \\
\text { case is found with similar characteristics [39]. }\end{array}$ \\
\hline & Intelligent agents & $\begin{array}{l}\text { Software programs working on a second plane without direct intervention } \\
\text { from people to conduct specific, repetitive, and predictable tasks for an } \\
\text { individual user, a business process, or a software application [40]. }\end{array}$ \\
\hline & Methods of problem solving & Problem solving techniques used in knowledge-based systems [41]. \\
\hline \multirow{5}{*}{$\begin{array}{l}\text { Social knowledge } \\
\text { management }\end{array}$} & Web 2.0 & $\begin{array}{l}\text { It is essential to comprehend change in the entrepreneurial environment. The } \\
\text { potential of networks, promoted by new innovations, leads the whole society } \\
\text { and enterprises to work faster, create and manage more interdependencies, and } \\
\text { operate in world markets" [11]. }\end{array}$ \\
\hline & Semantic networks & $\begin{array}{l}\text { It is the third generation of the web centered on filtering and processing useful } \\
\text { information for users and/or agents within a given context [42]. }\end{array}$ \\
\hline & Ontology & $\begin{array}{l}\text { "Each ontology is a treaty - a social agreement - among people w it h some } \\
\text { common motives to share" [43] }\end{array}$ \\
\hline & Groupware & $\begin{array}{l}\text { Software that supports the capacity of two or more people to communicate and } \\
\text { collaborate [44] }\end{array}$ \\
\hline & Virtual communities & $\begin{array}{l}\text { Acts as intermediary links between enterprises and online communities, } \\
\text { which guarantees a good relationship of both intermediaries. [7]. }\end{array}$ \\
\hline \multirow{3}{*}{ Knowledge at level } & Knowledge portals & $\begin{array}{l}\text { Organizing and communicating knowledge from employees so other } \\
\text { employees can use it to be more effective and productive in their work } \\
\text { [45]. }\end{array}$ \\
\hline & Intranet & $\begin{array}{l}\text { These are private networks. They provide a hypertext structure that facilitates } \\
\text { navigating among segments of information and can facilitate dynamic } \\
\text { exchange and the relationship of the information [46] }\end{array}$ \\
\hline & Directory of experts & $\begin{array}{l}\text { Knowledge acquisition through explanations, knowledge acquisition by } \\
\text { changing scenarios, acquisition through results of scenarios }\end{array}$ \\
\hline
\end{tabular}

Source: Author's elaboration

\section{Conclusions}

Currently, there is no single definition or identification of a specific process that can be replicated in all organizations regarding knowledge acquisition and representation; this is the norm that permits the scientific community to center its interests on its research. This interest becomes manifest in the need to create competitive advantage and strengthen the organizational culture for the creation of solid organizations that can adapt to current market changes. The case study identifying the implementation of some techniques of 


\section{TECCIENCIA}

knowledge representation within the organization, permits assuming that research on knowledge management have taken giant steps and that the techniques identified in the literature review can be adapted according to the situation or problem generated within the organization.

Knowledge acquisition and its representation permits organizations to generate value against the competition, facilitating their management of information, improving processes, interacting with new technologies, diminishing response times to problems identified, and offering quality products and services that permit satisfying the needs of the final user.

It may be inferred that these techniques of knowledge acquisition and representation will permit organizations to achieve its performance aimed at complying with the strategic plan traced; it also permits members of the organization to share and disseminate information across the organization to generate as a result optimal processes, generate competitive advantage, grow in the changing economy, and innovate.

This research will serve for future studies, on the analysis of the behavior of publications related to the theme of knowledge acquisition and representation linked to organizational development and to the generation of competitive advantage in organizations. Likewise, analyzing the support of knowledge management through information technologies and (CIT) and determining what is the impact it generates within the organization, as well as accomplishing to identify and subsequently implement these techniques supported on information technologies.

\section{Acknowledgements}

We thank Universidad Industrial de Santander, especially the INNOTEC research group from the School of Industrial and Entrepreneurial Studies, and the STI research group from the School of Systems Engineering for allowing us full development of this research. We also thank our tutors, MsC Luis Eduardo Becerra Ardila and MsC Laura Patricia Pinto Prieto, who were our guides during this research process and the start up of this study.

\section{Referencias}

[1] H. Shauer y S. C., «Modeling techniquesa for knowledge management,» de Knowledge management strategies. A handbook of applied technologies hershey information science reference, M Lytras, R Maier, A Naeve, M, Russ (Eds), 2008, pp. 91-115.

[2] I. Nonaka, «A dynamic theory of organizational knowledge creation,» Organization science, vol. 5, pp. 14-37, 1994.

[3] P. Drucker, Innovation and entrepreneurship: Practice and principles, New York: Mori Literay Agenci Inc., 1985.

[4] SOCIETIES, T. K., «Towards knowledge societies,» UNESCO Publications., 2005.

[5] L. E. Becerra, L. F. Sierra Joya y L. P. Pinto Prieto, «Tecnicas utilizadas en el proceso de adquisición de conocimiento: Una revisión sistemática en el área de management,» de 10th Latin American and caribbean conference for engineering and technology, 2012.

[6] A. Colin y M. Magda, «A framework for practising knowledge management,» Long Range Planning, vol. 35, pp. 49-71, 2002.

[7] M. Alavi y D. Leidner, «Review: knowledge managment and knowledge management systems: Conceptual foundations and research issues,» Management information systems research center university of minnesota, vol. 25, $\mathrm{n}^{\circ}$ 1, pp. 107-136, 2001.

[8] I. Nonaka y H. Takeuchi, «The knowledge creating company: How japanese companies crete the dynamics of innovation,» Harvard Bussiness Review, vol. 69, n 6, pp. 96-104, 1995.

[9] G. Stocker, «Gestion de conocimiento en la practica,» stocker group, 2013.

[10] M. Acuña, «Guia para la gestión del conocimiento,» Agencia Nacional de infraestructura, Bogotá, 2012.

[11] U. Witt, «How Evolucionary is schumpeter's theory of economic development?,» Industry and innovation, vol. 9, $\mathrm{n}^{\circ}$ 1, pp. 7-22, 2002

[12] B. Gaines, «Knowledge acquisition past, present and future,» International Journal of Human computer studies, vol. $71, \mathrm{n}^{\circ} 2$, pp. 135-156, 2013.

[13] J. Breuker, «A congnitive sicience perspective on knowledge acquisition,» International journal of Human computer studies, vol. 71, nº 2, pp. 177-183, 2013.

[14] F. Soria, «VII. Represetación del conocimiento,» de Sistemas Evolutivos, 1985.

[15] A. Rajendra y S. Priti, «Knowledge based- systems,» de Sudbury, Massachusetts:Pallai David, Jones \& Bartlett, 2010.

[16] M. Zuñiga, «Gestion y estrategia en personas: el enfoque del nuevo management,» Curso de reingenieria corporativa impartodo por la consultora certus soluciones estrategicas, Mexico, 2004

[17] j. Martin y W. Ken, «Visual strategizing the systematic use of visualization in strategic planning process,» Long range Planning, vol. 42, $\mathrm{n}^{\circ}$ 1, pp. 42-74, 2009.

[18] S. Blackwell y K. Pepper, «The effect of concept mapping on preservice teachers reflective practices when making pedagogical decisions,» The journal of effective teaching, vol. 8 , $\mathrm{n}^{\circ}$ 2, pp. 77-93, 2008.

[19] M. Peet, «Leadership transitions, m tacit knowledge sharing and organization generativity,» Journal of knowledge management, vol. 16, n ${ }^{\circ} 1$, pp. 45-60, 2012.

[20] R. Sparrow, R. Liden y M. Kraimer, «Social Networks and the performance of individual groups,» Academy of management journal, vol. 44, 2001.

[21] S. Bell, B. Menguc y R. Widing, «Salesperson learning, organizational learning and retail store performance,» Journal of the academy of marketing science, vol. $38, \mathrm{n}^{\mathrm{o}} 2, \mathrm{pp} .187-201$, 2010.

[22] D. Brachos, K. Kostopoulos, K. Soderquist, E. Klas y G. Prastacos, «Knowledge effectiveness, social context and innovation,» Journal of knowledge management, vol. 11, $\mathrm{n}^{\circ} 5$, pp. 1367-3270, 2007.

[23] H. Lin, «Knowledge sharing and firm innovation capability and 


\section{TECCIENCLA}

empirical study,» International journal of manpower, vol. $28, \mathrm{n}^{\circ}$ 3, pp. 315-332, 2007.

[24] S. Moffet, R. Mcadam y Parkinson., «An empirical analysis of knowledge management applications,» Journal of knowledge management, vol. 7, $\mathrm{n}^{\circ} 3$, pp. 6-26, 2003.

[25] C. Schoor y M. Bannert, «Motivation in a computer- supported collaborative learing scenario and its impact on learing activities and knowledge acquisition,» Learing and instruction, vol. $21, \mathrm{n}^{\circ}$ 4, pp. 560-573, 2011.

[26] J. M. George y A. P. Brief, «Motivational agendas in the workplace: the effects on focus of attention and work motivation.,» Research in organizational behavior, vol. 18, pp. 75-109.

[27] L. Luo, «Work Motivation, job stress and employees' weel being.,» Journal of applied management studies, vol. $8, \mathrm{n}^{\circ} 1$, pp. 61-72, 1999

[28] A. Brashear, C. Kowalkowski, J. Ritter, R. Marchetti y P. Prado, «Information seeking in complex industrial buying Empirical,» Evidence from Brazil, 2001.

[29] B. Bass y R. Riggio, «The transformational model of leadership,» Hickman Leading orgnizations : perspectives for a new era., CA Sage, 2010.

[30] J. Martocchino y T. Judge, «Relationship between conscientiousness and learning in employee training: mediating influences of self deception and self efficacy,» Journal of applied psiychology, vol. 82, 1997.

[31] P. Junni y R. Sarala, «Casual ambiguity, cultural integration and partner attractiviness as determinants of knowledge transfer evidence from finnish acquisitions,» European journal of international management, vol. 5, pp. 346-372, 2011.

[32] m. M. Hogg y D. Abrams, Social Identifications a social psychology on fintergroup relations and group processes, London: Rutledge, 1988.

[33] H. Tajfel, «Social Psychology of intergroup relations,» Anual review of psychology, vol. 33, $\mathrm{n}^{\circ} 1,1972$.

[34] m. R. Gulati, «Social Structure and Alliance Formation Patterns: A Longitudinal Analysis,» Administrative science quarterly, vol. 40, nº 4, pp. 619-652, 1995

[35] G. Ahuja, «The duality of collaboration: inducements and opportunities in the formation of interfirm linkages,» Strategic amanagement journal, vol. 21, $\mathrm{n}^{\circ} 3$, pp. 317-343, 2000.
[36] N. Rosenberg y R. Nelson, «American universities and technical advance in industry,» Research Policy, vol. 23, n 1, pp. 323348, 1994.

[37] K. Sherif y B. Xing, «Adaptative processes for knowledge creation in complex systems: the case o a global IT consulting firm,» Information \&management, vol. 43, $\mathrm{n}^{\circ} 1$, pp. 530-540, 2006.

[38] K. M. Wiig, «Knowledge management: Where did it come from and where will it go?,» Expert systems with applications, vol. 13, no 1, pp. 1-14, 1997.

[39] V. Botti, C. Crrascosa, V. Julia y J. Soler, «Modelling Agents in Hard Real-Time Environments,» Multi-Agent System Engineering lecture notes in computer science, vol. 1647, pp. 63-76, 1999

[40] C. Cheung y F. Li, «A. quantitative correlation coefficient mining method for business intelligence in small and medium enterprises of trading business,» Expert systems with applications, vol. 39, $\mathrm{n}^{\circ}$ 7, pp. 6279-6291, 2012.

[41] B. Kalpic y P. Bernus, «Business process modeling through the knowledge management perspective,» Journal of Knowledge Management, vol. 10, $\mathrm{n}^{\circ}$ 3, pp. 40-56, 2006.

[42] M. Bosch, «Ontologies, Different Reasoning Strategies, Different Logics, Different Kinds of Knowledge,» Knowledge Organization, Ergon Verlag, vol. 33, n 3, pp. 153-159, 2006.

[43] A. Gonzalez y R. Suárez, «Trabajo cooperativo con computadora aplicado en plataforma de enseñanza y aprendizaje Nexus de la UANL,» RISCE Revista Internacional de sistemas computacionales y electronicos, vol. $6, \mathrm{n}^{\circ} 3,2011$.

[44] F. Garrigos- Simon, R. Lapiedra Alcami y T. Barberá Ribera, «Social networks and Web 3.0: their impact on the managemen and marketing of organizations,» Management Decision, vol. 50, $\mathrm{n}^{\circ} 10$, pp. 1880-1890, 2012.

[45] A. Fernández Hernández, «Arquitectura de información de los portales intranets: un componente esencial de la gestión de información en las universidades,,» Acimed, vol. 19, n 4 , pp. 111, 2009.

[46] S. S. Abidi, Y. N. Cheah y J. Curran, «A knowledge creation info-structure to acquire and crystallize the tacit knowledge of health-care experts.,» IEEE Transactions on information technology in biomedicine, vol. 9, nº 2, pp. 193-204, 2005. 